UDC 621.314

\title{
Steady-State Process Analysis of DC Converter Based on Equations Expansion
}

\author{
Korotyeyev I., Dr.Sc. Prof., ORCID 0000-0002-7990-5413 \\ Institute of Electrical Engineering \\ University of Zielona Góra, ROR 04fzm7v55 \\ Zielona Góra, Poland
}

Klytta M., Dr.Sc. Prof., ORCID 0000-0002-6832-0145

Dep. Electrotechnics and Information Technology

Mittelhessen Univ. of Applied Sciences, ROR 02qdc9985

Gießen, Germany

\begin{abstract}
The paper deals with processes analysis in circuits of converter working on a time-varying load. A control of inverter and load switches are realised by signals with incommensurable frequencies. Processes in such a system are described by differential equations with periodical coefficients. Steady-state periodic solutions can be obtained by the extension of ordinary differential equations with one independent time variable into partial differential equations with two independent variables of time. These equations are solved by use of the Galerkin method with trigonometric basis and weight functions. The results of calculations of the steady-state process for a buck-boost converter are presented in form of the double Fourier series. They are compared with results obtained in the way of numerical calculation of differential equations for a transient process. Extended equations are also solved by a generalized state-space averaging method. A balance of active power in circuits of converter with the time-varying load is shown.
\end{abstract}

Key words - expansion of differential equations; double Fourier series; Galerkin method

\section{INTRODUCTION}

DC converters are used to energy supply of loads with constant and varied structure. If DC converter works on a varied load, the processes in the circuit are described by differential equations with periodic coefficients. Processes in such a system can be analysed using analytical and numerical methods [1]-[7]. One can also use the state-space average model [8] based on the integral calculation

$$
\frac{1}{T} \int_{t-T}^{t} X(t) d t
$$

where $X(t)$ is a vector of state variables.

If commutation periods of the converter and loads switches are incommensurable, one can use methods described in [9], [10]. An extension of differential equation is shown in [10] and an approximation of solutions in [9]. It should be mentioned, that in case of incommensurable frequencies, state-space average models cannot be used. In order to simplify a calculation procedure of processes it is expedient to use both tools, i.e. the extension of differential equations and the approximation of solutions [11].

The aim of this paper is to present methods based on the differential equations extension and on use of the Galerkin method [12]. The differential equations with variable coefficients, dependent on two incommensurable control signals, are extended by introducing of two independent time variables. The extension of differential equations with one variable of time $t$ is implemented by transition to partial differential equations dependent on two independent time variables $t$ and $\tau$. The solution is found by use of the Galerkin method with trigonometric basis and weight functions. Obtained solutions are described by a double Fourier series. An extended lagged running average procedure is used in order to generalize the state-space averaging method. Periodic steady-state current and voltage in circuits of Buck Boost DC converter are calculated. Obtained results are used to calculate a balance of active power in the converter circuits, the RMS voltages on a capacitor and an inductor current. Results of calculations are also compared with results obtained by a numerical method.

\section{MATHEMATICAL MODEL}

Let us analyse a steady-state process in the DC Buck Boost converter with a time-varying load. The circuit diagram of the converter is presented in Fig. 1.

The switches $S_{1}, S_{2}$ and $S_{3}$ are ideal. If the switch $S_{1}$ is on, the switch $S_{2}$ is off and vice-versa. The switching function $s(t)$ for the switches $S_{1}$ and $S_{2}$ is shown in Fig. 2. When $s(t)=1$, the switch $S_{1}$ is turned on.

The switch $S_{3}$ switches a part of the load. The switching function $\gamma(t)$ corresponded to states of the switch $S_{3}$ 
(when $\gamma(t)=1$ then switch $S_{3}$ is on) is shown in Fig. 2 . We also assume, that resistors, capacitors and inductors are linear elements.

Processes in circuits of the converter are described by differential equations

$$
\begin{aligned}
& \frac{d i(t)}{d t}=-\frac{r}{L} i(t)-\frac{1-s(t)}{L} u(t)+\frac{s(t) E}{L}, \\
& \frac{d u(t)}{d t}=\frac{1-s(t)}{C} i(t)-\frac{\gamma(t) R_{1}+R_{2}}{R_{1} R_{2} C} u(t) ;
\end{aligned}
$$

where $r$ is a resistance of the inductor. These equations can be written in matrix form as follows

$$
\frac{d X(t)}{d t}=A(t) X(t)+B(t)
$$

where $X(t)=\left|\begin{array}{l}i(t) \\ u(t)\end{array}\right|$ is the vector of state variables.

$$
A(t)=\left|\begin{array}{cc}
-\frac{r}{L} & -\frac{1-s(t)}{L} \\
\frac{1-s(t)}{C} & -\frac{\gamma(t) R_{1}+R_{2}}{R_{1} R_{2} C}
\end{array}\right|, B(t)=\left|\begin{array}{c}
\frac{s(t) E}{L} \\
0
\end{array}\right| .
$$

In order to solve the differential equation (4) to any possible frequencies of control signals we extend this equation to the partial differential equation with two independent variables of time $t$ and $\tau$ in the following way [10]

$$
\frac{\partial X(t, \tau)}{\partial t}+\frac{\partial X(t, \tau)}{\partial \tau}=A(t, \tau) X(t, \tau)+B(t)
$$

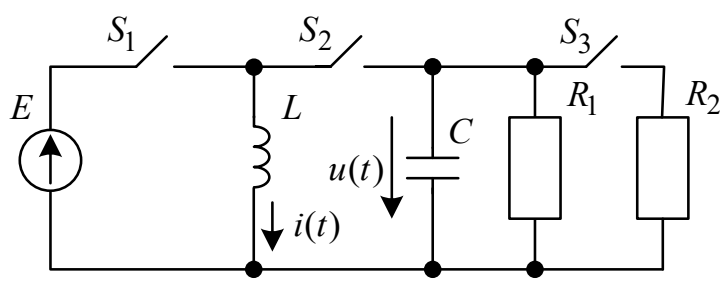

Fig. 1. Circuit diagram of DC Buck Boost converter

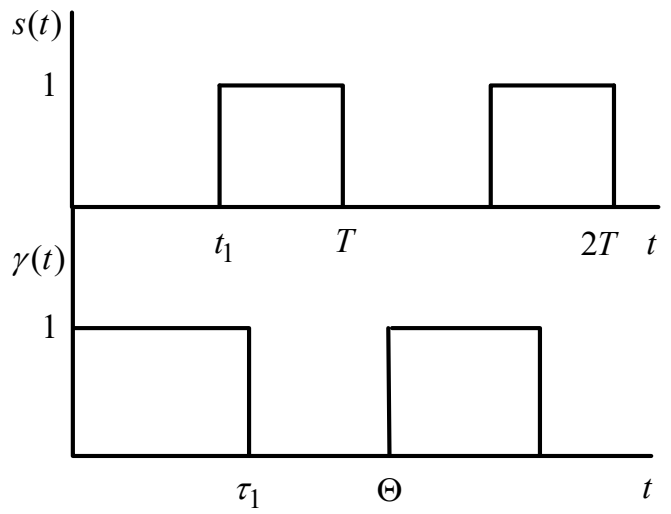

Fig. 2. Switching functions where $A(t, \tau)=\left|\begin{array}{cc}-\frac{r}{L} & -\frac{1-s(t)}{L} \\ \frac{1-s(t)}{C} & -\frac{\gamma(\tau) R_{1}+R_{2}}{R_{1} R_{2} C}\end{array}\right|$

In this equation periods $T$ and $\Theta$ are incommensurable. In order to obtain a periodic steady-state solution, we use trigonometric functions and present this solution in the form of the double Fourier series.

\section{CALCULATION OF STEADY-STATE PROCESS}

Let us solve (5) using the Galerkin method, which is based on finding of the residuum of the differential equations [12]

$$
R_{X(t)}=\frac{d X(t)}{d t}-A(t) X(t)-B(t)
$$

over the period. Then this residuum is multiplied by weight functions and the obtained expression integrates over the period. Obtained solutions are used to find an approximate value of the vector of state variables.

For the equation with two-time variables (5) the residuum (6) is also extended as follows

$$
R_{X(t, \tau)}=\frac{\partial X(t, \tau)}{\partial t}+\frac{\partial X(t, \tau)}{\partial \tau}-A(t, \tau) X(t, \tau)-B(t)
$$

over the area $0 \leq t \leq T, 0 \leq \tau \leq \Theta$.

We use trigonometric functions as basis and weight functions for finding the periodic steady-state solution

$$
\begin{aligned}
& \varphi_{n, k}(t, \tau)=\sin (n \omega t) \sin (k \Omega \tau) \\
& \psi_{n, k}(t, \tau)=\sin (n \omega t) \cos (k \Omega \tau) \\
& \eta_{n, k}(t, \tau)=\cos (n \omega t) \sin (k \Omega \tau) \\
& \xi_{n, k}(t, \tau)=\cos (n \omega t) \cos (k \Omega \tau)
\end{aligned}
$$

where $n=0,1,2, \ldots, k=0,1,2, \ldots \omega=\frac{2 \pi}{T}, \Omega=\frac{2 \pi}{\Theta}$.

In that case a periodic steady-state solution $X(t, \tau)$ is described by the double Fourier series [13]

$$
\tilde{X}(t, \tau)=\left|\begin{array}{c}
\tilde{i}(t, \tau) \\
\tilde{u}(t, \tau)
\end{array}\right|,
$$

where

$$
\begin{gathered}
\tilde{i}(t, \tau)=\sum_{n=0}^{N} \sum_{k=0}^{N}\left[\begin{array}{c}
i_{n, k}^{\varphi} \varphi_{n, k}(t, \tau)+i_{n, k}^{\psi} \psi_{n, k}(t, \tau)+ \\
+i_{n, k}^{\eta} \eta_{n, k}(t, \tau)+i_{n, k}^{\xi} \xi_{n, k}(t, \tau)
\end{array}\right] \\
\tilde{u}(t, \tau)=\sum_{n=0}^{N} \sum_{k=0}^{N}\left[\begin{array}{c}
u_{n, k}^{\varphi} \varphi_{n, k}(t, \tau)+u_{n, k}^{\psi} \psi_{n, k}(t, \tau)+ \\
+u_{n, k}^{\eta} \eta_{n, k}(t, \tau)+u_{n, k}^{\xi} \xi_{n, k}(t, \tau)
\end{array}\right]
\end{gathered}
$$

in which $i_{n, k}^{\varphi}, i_{n, k}^{\psi}, i_{n, k}^{\eta}, i_{n, k}^{\xi}, u_{n, k}^{\varphi}, u_{n, k}^{\psi}, u_{n, k}^{\eta}, u_{n, k}^{\xi}$ are coefficients for the searched current and voltage and $N$ is the chosen number of terms.

Therefore (7) takes the form 


$$
\begin{aligned}
\tilde{R}_{X(t, \tau)}= & \frac{\partial \tilde{X}(t, \tau)}{\partial t}+\frac{\partial \tilde{X}(t, \tau)}{\partial \tau}- \\
\tilde{R}_{X(t, \tau)}= & \frac{\partial \tilde{X}(t, \tau)}{\partial t}+\frac{\partial \tilde{X}(t, \tau)}{\partial \tau}- \\
& -A(t, \tau) \tilde{X}(t, \tau)-B(t)
\end{aligned}
$$

After multiplying of (7) by the weight functions (8-11) and integrating we obtain following expressions

$$
\begin{aligned}
& \int_{0}^{T} \int_{0}^{\Theta} R_{X(t, \tau)} \varphi_{n, k}(t, \tau) d t d \tau=0 \\
& \int_{0}^{T} \int_{0}^{\Theta} R_{X(t, \tau)} \psi_{n, k}(t, \tau) d t d \tau=0 \\
& \int_{0}^{T} \int_{0}^{\Theta} R_{X(t, \tau)} \eta_{n, k}(t, \tau) d t d \tau=0 \\
& \int_{0}^{T} \int_{0}^{\Theta} R_{X(t, \tau)} \xi_{n, k}(t, \tau) d t d \tau=0
\end{aligned}
$$

From the set (16-19) one calculates coefficients for the steady-state current and voltage.

Let us consider a lagged running average procedure for extended equations

$$
\frac{1}{T \Theta} \int_{t-T}^{t} \int_{\tau-\Theta}^{\tau} X(t, \tau) d \tau d t
$$

This expression extends (1) and allows finding the averaged state-space model. Using (20) one obtains the averaged state-space model for the DC Buck Boost converter

$$
\frac{d \hat{X}(t, \tau)}{d t}=A(d, \delta) \hat{X}(t, \tau)+B(d)
$$

where $\hat{X}(t, \tau)=\left(\begin{array}{l}\hat{i}(t, \tau) \\ \hat{u}(t, \tau)\end{array}\right)$ is a vector of averaged state variables;

$$
\begin{gathered}
A(d, \delta)=\left(\begin{array}{cc}
-\frac{r}{L} & -\frac{1-d}{L} \\
\frac{1-d}{C} & -\frac{\delta R_{1}+R_{2}}{R_{1} R_{2} C}
\end{array}\right) ; B(d)=\left|\begin{array}{c}
\frac{d E}{L} \\
0
\end{array}\right| ; \\
d=\frac{t_{1}}{T} ; \delta=\frac{\tau_{1}}{\Theta} .
\end{gathered}
$$

Solving (21) for steady-state one obtains

$$
\hat{X}=-A(d, \delta)^{-1} B(d)
$$

where $A(d, \delta)^{-1}$ is the inverse matrix; $\hat{X}=\left(\begin{array}{l}\hat{i} \\ \hat{u}\end{array}\right)$ is a vector of averaged steady-state variables,

$$
\hat{u}=\frac{(1-d) d R_{1} R_{2} E}{d^{2} R_{1} R_{2}+r\left(R_{1}-R_{1} \delta+R_{2} \delta\right)}
$$

$$
\hat{i}=\frac{(1-d)\left(R_{1}-R_{1} \delta+R_{2} \delta\right) E}{d^{2} R_{1} R_{2}+r\left(R_{1}-R_{1} \delta+R_{2} \delta\right)}
$$

Let us calculate the power consumption of the timevarying load as follows

$$
P_{L}=\frac{1}{T \Theta} \int_{0}^{T} \int_{0}^{\Theta} \frac{u(t, \tau)^{2}\left[\gamma(\tau) R_{1}+R_{2}\right]}{R_{1} R_{2}} d t d \tau
$$

In turn, the power dissipated by the resistance of an inductor is [14]

$$
P_{r}=\frac{1}{T \Theta} \int_{0}^{T} \int_{0}^{\Theta} r i(t, \tau)^{2} d t d \tau
$$

The Buck Boost converter converts the active power as follows

$$
P_{E}=\frac{1}{T \Theta} \int_{0}^{T} \int_{0}^{\Theta} s(t) \operatorname{Ei}(t, \tau) d t d \tau
$$

In what follows we will see that a balance of active power for such a system remains.

\section{SIMULATION RESULTS}

Let us calculate the steady-state process for the element values: $r=0.556 \Omega, C=167 \mu F \quad L=1.11 \mathrm{mH}$, $R_{1}=3 \Omega, R_{2}=10 \Omega, E=44.4 \mathrm{~V}, \omega=9 \mathrm{kHz}, \Omega=\pi \omega$, $t_{1}=0.6 T, \tau_{1}=0.34 \Theta$. The integrals (16-19) are calculated by the use of Mathematica for arbitrary $n$ and $k$ numbers. We also take into account that the trigonometric functions (8-11) are used and the switching functions depend on one argument.

The steady-state current and voltage in circuits of the Buck Boost converter for two periods and for $N=3$ are presented in Fig. 3 and Fig. 4. These results do not practically change when calculated for greater chosen $N$.

In order to obtain processes in the domain of one time variable one equals $t$ to $\tau$. The steady-state current in the inductor and voltage across the capacitor are shown in Fig. 5 and Fig. 6 (curve 1). There are also presented the results obtained by the numerical method embedded in Mathematica (curve 2) as well as lines corresponded to extended state-space averaging method (line 3) and mean values evaluated by numerical method (line 4). Processes calculated by the proposed and numerical methods coincide practically for all points.

The output voltage of DC Buck Boost converter vs. duty cycles calculated by (23) is shown in Fig. 7.

The active powers, the RMS voltage and current calculated by the proposed method, by generalised statespace averaging method as well as by numerical method are presented in Table 1.

As one can see that the values calculated by the numerical method tend to the values calculated by the proposed method when the interval of calculation is increased. 


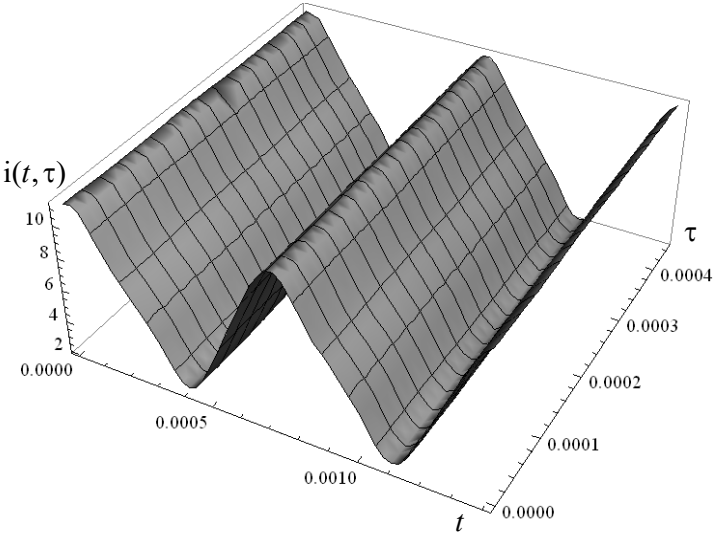

Fig. 3. Steady-state current in the circuit of the Buck Boost converter for two periods $0 \leq t \leq 2 T, 0 \leq \tau \leq 2 \Theta$

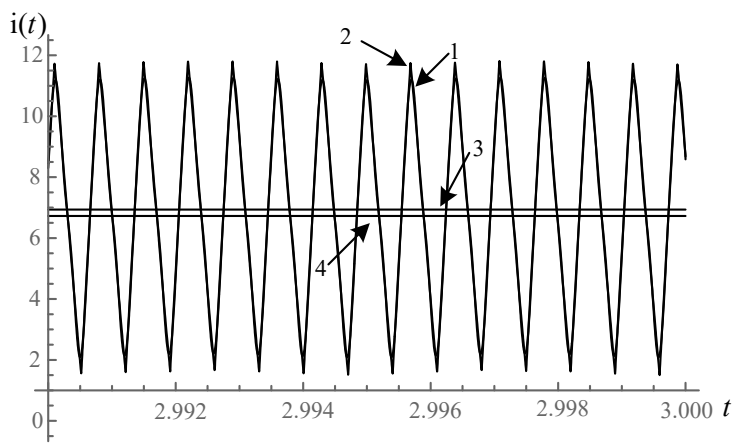

Fig. 5. Steady-state current in the inductor of the Buck Boost converter: 1- the described method for $N=3 ; 2$ - the numerical method; 3 - the state-space averaging method; 4 - the mean value evaluated by numerical method

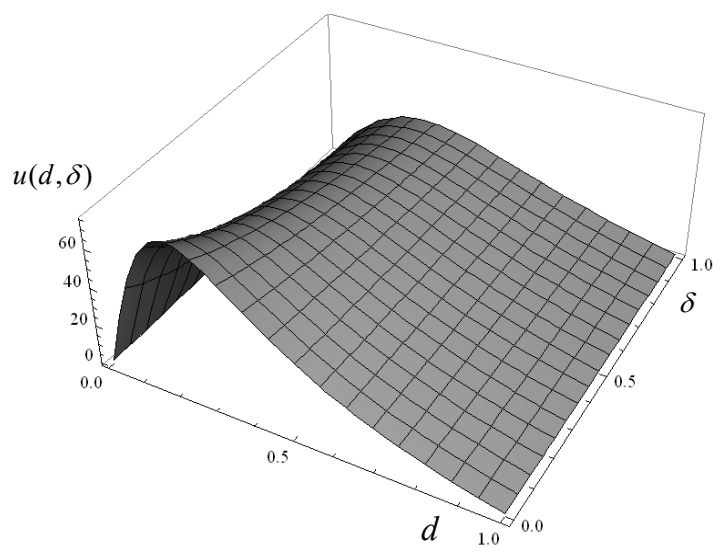

Fig. 7. Output voltage vs. duty cycles

TABLE 1

\begin{tabular}{|l|l|l|l|}
\hline \multicolumn{1}{|c|}{ Method } & Power, W & $\begin{array}{c}\text { RMS volt- } \\
\text { age, V }\end{array}$ & $\begin{array}{c}\text { RMS cur- } \\
\text { rent, A }\end{array}$ \\
\hline Proposed method & 120.723 & 22.495 & 7.36 \\
\hline $\begin{array}{l}\text { State-space aver- } \\
\text { aging method }\end{array}$ & 123.314 & 23.21 & 6.94 \\
\hline $\begin{array}{l}\text { Numerical } \\
\text { method: interval } \\
\text { of calculation is T } \\
\text { interval of calcu- } \\
\text { lation is 17T }\end{array}$ & 119.668 & 22.567 & 7.311 \\
\hline
\end{tabular}

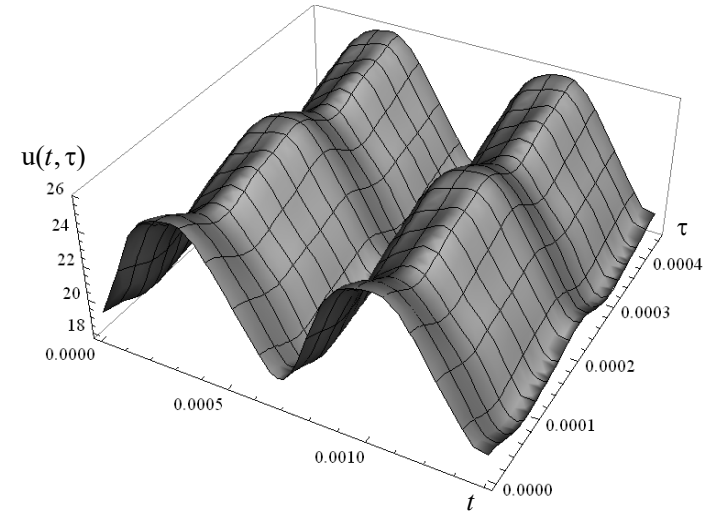

Fig. 4. Steady-state voltage in the circuit of the Buck Boost converter for two periods $0 \leq t \leq 2 T, 0 \leq \tau \leq 2 \Theta$

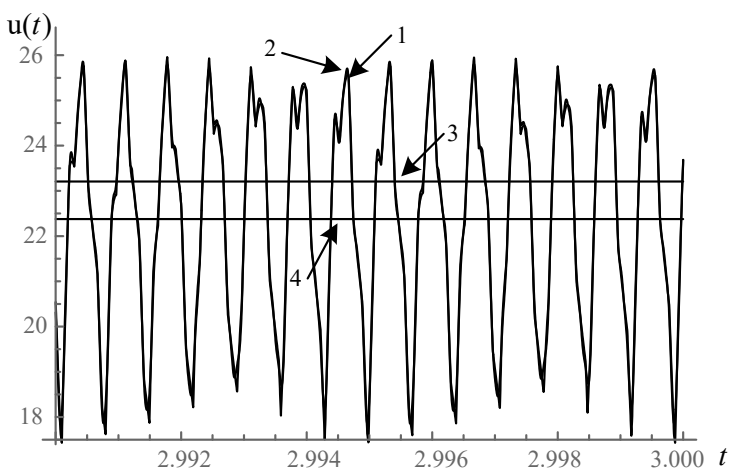

Fig. 6. Steady-state voltage across the capacitor of the Buck Boost converter: 1- the described method for $N=3 ; 2$ - the numerical method; 3the state-space averaging method; 4 - the mean value evaluated by numerical method

The active power calculated by (26) is $P_{E}=120.723$ $\mathrm{W}$. The power on the load calculated by (24) is $90.668 \mathrm{~W}$ and the power dissipated on resistance of an inductor is $P_{r}=30.055 \mathrm{~W}$. It is easy to check that $P_{E}=P_{L}+P_{r}$

\section{CONCLUSIONS}

This paper shows calculation of steady-state processes in Buck Boost converter circuits with a time-varying load. The calculation is realised in the way of extension of differential equations in the domain of two variables of time and of the use of the Galerkin method. Use of trigonometric functions allow to present steady-state processes in form of the double Fourier series. The generalized average procedure has been introduced. Steady-state processes in the circuit of a DC Buck Boost converter has been calculated using the described method, a numerical method and generalized state space averaging method. The obtained results have been used to calculate the balance of active power and the RMS values of current and voltage. The comparison of results by using the proposed method with results of calculation obtained by the numerical method shown good coincidence. 


\section{REFERENCES}

[1] W. R. Bennett, "Steady-state transmission through networks containing periodically operated switches," IRE Trans. Circuit Theory, vol. 2, no. 1, pp. 17-21, Mar. 1955, DOI: $10.1109 / \mathrm{TCT} .1955 .6500148$

[2] C. A. Desoer, "A Network Containing a Periodically Operated Switch Solved by Successive Approximations," Bell Syst. Tech. J., vol. 36, no. 6, pp. 1403-1428, Nov. 1957, DOI: $10.1002 / \mathrm{j} .1538-7305.1957 . t b 01516 . x$.

[3] G. W. Hill, "On the part of the motion of the lunar perigee which is a function of the mean motions of the sun and moon," Acta Math., vol. 8, pp. 1-36, 1886, DOI: 10.1007/BF02417081.

[4] Ming-Lei Liou, "Exact Analysis of Linear Circuits Containing Periodically Operated Switches with Applications," IEEE Trans. Circuit Theory, vol. 19, no. 2, pp. 146-154, 1972, DOI: $10.1109 /$ TCT.1972.1083438

[5] A. Pels, J. Gyselinck, R. V. Sabariego, and S. Schops, "Efficien Simulation of DC-DC Switch-Mode Power Converters by Multirate Partial Differential Equations," IEEE J. Multiscale Multiphysics Comput. Tech., vol. 4, pp. 64-75, 2019, DOI: 10.1109/JMMCT.2018.2888900.

[6] R. Trinchero, I. S. Stievano, and F. G. Canavero, "Steady-State Response of Periodically Switched Linear Circuits via Augmented Time-Invariant Nodal Analysis," J. Electr. Comput. Eng., vol. 2014, pp. 1-11, 2014, DOI: $\underline{10.1155 / 2014 / 198273}$

[7] L. A. Zadeh, "Frequency Analysis of Variable Networks," Proc. IRE, vol. 38, no. 3, pp. 291-299, Mar. 1950,

DOI: $10.1109 /$ JRPROC. 1950.231083 .

Надійшла до редакції 18 червня 2020 р.
[8] R. D. Middlebrook and S. Cuk, "A general unified approach to modelling switching-converter power stages," in 1976 IEEE Power Electronics Specialists Conference, 1976, pp. 18-34, DOI: $10.1109 /$ PESC.1976.7072895.

[9] H. G. Brachtendorf, G. Welsch, R. Laur, and A. Bunse-Gerstner, "Numerical steady state analysis of electronic circuits driven by multi-tone signals," Electr. Eng., vol. 79, no. 2, pp. 103-112, Apr. 1996, DOI: $10.1007 / \mathrm{BF} 01232919$.

[10] I. Korotyeyev, V. Zhuikov, and R. Kasperek, Electrotechnical systems. Calculation and analysis with Mathematica and PSpice. CRC Press, 2010.

[11] I. Korotyeyev, "Steady-state analysis of DC converter using Galerkin's method," COMPEL - Int. J. Comput. Math. Electr. Electron. Eng., vol. 38, no. 6, pp. 2057-2069, Oct. 2019, DOI: $10.1108 /$ COMPEL-02-2019-0062.

[12] K. Rektorys, Variational Methods in Mathematics, Science and Engineering. Dordrecht: Springer Netherlands, 1977, ISBN: 978-94-011-6452-8

[13] G. P. Tolstov, Fourier Series. Dover Publications, 1976, ISBN: 9780486141749.

[14] I. Korotyeyev and M. Klytta, "Analyse of steady-state process in circuits with incommensurable frequencies of voltage sources," in 2016 2nd International Conference on Intelligent Energy and Power Systems (IEPS), 2016, pp. 1-4,

DOI: $10.1109 /$ IEPS.2016.7521846. 


\section{Аналіз процесу перетворювача постійної напруги, що встановився заснований на розширенні рівнянь}

Коротєєв I. Є., д.т.н. проф., ORCID 0000-0002-7990-5413

Institute of Electrical Engineering

Зеленогурский університет, ROR 04fzm7v55

Зелена Гура, Польща

Клитта М., д.т.н. проф., ORCID $\underline{0000-0002-6832-0145}$

Технологічний факультет електротехніки та інформатики Технічний університет центральної Гесії, ROR $\underline{02 q d c 9985}$

Гіссен, Германія

Анотація-Стаття присвячена аналізу процесів в ланцюгах інвертора, працюючого на змінне навантаження. Управління ключами інвертора і навантаження здійснюється періодичними сигналами, частоти яких не є кратними. Процеси в такій системі описуються диференційними рівняннями 3 періодичними коефіціснтами. Усталені періодичні рішення можуть бути отримані шляхом розширення звичайних диференційних рівнянь 3 однісю незалежною змінною часу в рівняння з частковими похідними 3 двома змінними часу. Ці рівняння вирішуються за допомогою методу Гальоркіна, базисні і вагові функції якого с тригонометричними. Наближене рішення представлясться у вигляді розкладання по базису, тригонометричні функції якого с функціями двох аргументів. Для знаходження системи рівнянь використовусться властивість ортогональності нев'язкі по відношенню до системи вагових функцій. Розрахунок ортогональності грунтується на обчисленні подвійних інтегралів твору нев'язкі на вагові функції. Знаходження усталеного процесу інвертуючого перетворювача робиться в результаті рішення отриманої системи рівнянь алгебри. Отримані рішення системи рівнянь алгебри представляється у формі подвійного ряду Фур'с. Отримані результати порівнюються з чисельним розрахунком диференційних рівнянь. Чисельний розрахунок усталеного процесу робиться після розрахунку перехідного процесу. Представлено узагальнення методу усереднення для простору двох змінних часу. Отримане, в результаті усереднення цим методом, диференційне рівняння використовується для знаходження узагальнених усереднених усталених значень. Представлені вирази для розрахунку активної потужності в ланцюгах інвертора, засновані на використанні подвійних інтегралів. Зроблений розрахунок активної потужності, що віддається джерелом живлення і активної потужності, що розсівається в ланцюгах інвертора і змінного навантаження. Розрахунок підтверджує наявність балансу активної потужності в ланцюгах інвертора зі змінним навантаженням.

Ключові слова - розщирення диференційних рівнянь; подвійний ряд Фур'є; метод Гальоркіна. 